\title{
Quality of life and epilepsy surgery in childhood and adolescence
}

\author{
Isabella C. Gagliardi', Catarina A. Guimarães², Elisabete A.P. Souza², \\ Kátia M.R. Schmutzler ${ }^{3}$, Marilisa M. Guerreiro ${ }^{4}$
}

\begin{abstract}
Epilepsy can affect the quality of life (QOL) of patients. The temporal lobe epilepsy (TLE) is often refractory to medication, which has an adverse impact on $\mathrm{QOL}$. The surgery can be a form to control the seizures and to improve the $\mathrm{QOL}$ of the patients. Objective: The aim of this study was to verify the $\mathrm{QOL}$ of children and adolescents with TLE who underwent surgery for epilepsy, comparing $\mathrm{QOL}$ before and after surgery and investigating which parameters showed improvement. Method: We used semi-structured questionnaire in the pre-and post-surgery in 13 patients. The data were analyzed using the Wilcoxon test. Results: The analysis showed that there was general improvement in the $\mathrm{QOL}$ postoperatively. There was improvement in general health issues, adverse effects of antiepileptic drugs and the relationship with parents. Conclusion: When properly indicated, epilepsy surgery improves quality of life of patients with TLE.
\end{abstract}

Key words: temporal lobe epilepsy, quality of life, surgery.

\section{Qualidade de vida e cirurgia de epilepsia na infância e adolescência}

\section{RESUMO}

Epilepsia pode afetar a qualidade de vida (OV) de pacientes. A epilepsia de lobo temporal (ELT) é frequentemente refratária ao tratamento medicamentoso, o que tem impacto negativo na QV. A cirurgia pode trazer controle das crises e melhorar a QV de pacientes com epilepsia. Objetivo: O objetivo desse estudo foi verificar a QV de crianças e adolescentes com ELT que foram submetidos à cirurgia para epilepsia, comparando a QV antes e após a intervenção cirúrgica, verificando quais foram os parâmetros que apresentaram melhora. Método: Um questionário semi-estruturado foi aplicado durante a avaliação pré e pós cirúrgica em 13 pacientes. Os dados foram analisados utilizandose o teste de Wilcoxon. Resultados: A análise mostrou que houve melhora global da QV no pós-operatório. Houve melhora em aspectos gerais da saúde, eventos adversos de drogas antiepilépticas e relacionamento com os pais. Conclusão: Quando adequadamente indicada, a cirurgia para epilepsia melhora a OV de pacientes com ELT.

Palavras-chave: epilepsia de lobo temporal, qualidade de vida, cirurgia.

\section{Correspondence}

Marilisa M. Guerreiro

Dep. Neurologia / FCM / UNICAMP

Caixa Postal 6111

13083-970 Campinas SP - Brasil

E-mail:mmg@fcm.unicamp.br

\section{Support}

Catarina A. Guimarães and Isabella Gagliardi received scholarship from FAPESP (grants number \# 06/56257-6 and 08/55750-6)

Received 15 March 2010

Received in final form 2 June 2010 Accepted 9 June 2010
Epilepsy is not a single condition, but a group of diseases that presents with recurrent epileptic seizures in the absence of a toxic-metabolic or febrile condition ${ }^{1}$. Epilepsy is one of the most common neurological diagnoses. Because it also implicates economic aspects, it becomes a public health problem².

Due to the seizures and their chronic characteristic, epilepsy is a condition that changes the life of the patients both phys- ically and psychosocially. Therefore, concern about quality of life (QOL) of the patients is increasing ${ }^{1,3}$. Quality of life is defined as the perception by the patient of his/her own physical, mental, emotional and social well-being, and his/her perception of how the disease has altered his/ her life ${ }^{4}$.

The diagnosis of epilepsy is accompanied by social stigma, which is often associated with a lack of information, result- 
ing in the imposition of restrictions on many aspects of the patient's life ${ }^{3,5}$. In adults, epilepsy has a negative impact on profession, marriage, general and mental health. In childhood, it affects the physical and cognitive health of the child and his psychosocial adjustment ${ }^{6,7}$.

Studies on the psychosocial impact of children's epilepsy have shown an association between emotional and behavioral problems and the disease ${ }^{8}$. In teenagers, the consequences might be even more negative, since this period of life is marked by significant changes ${ }^{4}$.

With the purpose of evaluating QOL of epileptic patients, many instruments (for adults and children), general and specific for epilepsy, have been used ${ }^{6,7,9-12}$. A common finding from these evaluations is that refractory epilepsy is a condition that impacts directly and negatively on the QOL of the patients, mostly worsening social integration $^{3}$. Refractory epilepsy is defined as inadequate seizure control despite appropriate medical therapy with anti-epileptic drugs (AEDs) or adequate seizure control, but with unacceptable side effects ${ }^{13}$.

In refractory cases, epilepsy surgery may control the seizures $^{1,3,13}$. The aim of the surgery is not only to control the seizures, but also to improve the QOL of the patients ${ }^{14}$. The comparison between presurgical evaluation with postsurgical assessment allows us to analyze how much the patient improved and in which aspects of QOL the performance is better. Among several types of surgical procedures, temporal lobe epilepsy (TLE) surgery usually has the better outcome.

The aim of this study was to verify the QOL of children and adolescents with temporal lobe epilepsy who underwent surgery for epilepsy, comparing QOL before and after surgery and investigating which parameters showed improvement.

\section{METHOD}

We evaluated 13 patients using a semi-structured questionnaire $^{15}$.

The inclusion criteria were: to have undergone surgery for refractory TLE at HC/UNICAMP; to have previously answered the same QOL questionnaire during the preoperative assessment; either the patient or the guardian must have signed the informed consent form.

The QOL questionnaire given to the epilepsy surgery patient consists of seven parts concerning personal identification and information about the disease (including the perception item of seizure control); general health issues (physical, emotional, social, educational and leisure); physical issues (possible limitations to physical activities practiced by the patient); side effects of medication; psychological aspects (data on behavior, emotional and cognitive abilities of the child: concentration, memory, language and motor skills); social aspects (social interaction, leisure and schooling); and environmental influences (parental behavior towards the child $)^{14}$.

A direct interview (with objective and closed responses) was conducted by the researcher with the guardian (or with the patient him/herself). The answers were chosen on a scale of one to three (referring, respectively, to the concepts "a lot", "a little" and "no"), so that the higher the score, the better the QOL.

A table was set up with the scores of each patient and the compilation of data was submitted to statistical analysis with the nonparametric Wilcoxon test. We considered the significance level of 0.05 .

The study was approved by the Ethics Committee of UNICAMP.

\section{RESULTS}

We interviewed 13 patients, seven females and six males. In this sample, ages ranged from 11 to 21 years, with a mean age of 15.4 years. The mean follow-up (between the pre- and postoperative interview) was 3.8 years (ranging from 7 months to 10 years).

One of the variables studied was the item "Perception of Control of Seizures". Before surgery for TLE, 10 of the patients evaluated (76.92\%) denied any seizure control and three of them (23.08\%) reported a subtle control. After surgery, the 13 patients (100\%) reported very good control over the occurrence of seizures.

One should also mention that currently only eight patients (61.54\%) remain on drug treatment with AEDs.

The clinical data cited above are outlined in Table 1.

Table 2 shows the results for each item assessed: general health, physical aspects, effects of antiepileptic medication, emotional behavior, cognitive aspects, social aspects and schooling, and the relationship with parents. From the analysis of these data, this study found that epilepsy surgery improves the QOL of patients with refractory TLE. The statistically significant variables were: general health, negative effects of AEDs and behavior of parents toward the child.

\section{DISCUSSION}

This study aimed to investigate the impact of surgery for refractory TLE on the QOL of patients. For greater reliability in the study, we used the same questionnaire previously applied in the preoperative assessment.

In the preoperative evaluation of QOL, 15 patients were interviewed and 13 of these participated in this study. The number of subjects is certainly small for a quantitative analysis, however, the focus of this work is qualitative, comparing QOL in the two periods (pre- and postoperative) of the subject with himself and with the data set. The number of patients is also small in many other studies that addressed the impact of surgery on QOL of epileptic patients ${ }^{3,14,16-23}$. 
Table 1. Clinical data of interviewed patients.

\begin{tabular}{cccccc}
\hline Patient & Gender & Age* $^{*}$ & Time between interviews & Total score total pre- / post-operative & CP** pre- / post-operative \\
\hline 1 & $F$ & $14 y$ & $7 y 11 m$ & $117 / 174$ & $1 / 3$ \\
2 & $F$ & $12 y$ & $10 y$ & $156 / 161$ & $1 / 3$ \\
3 & $F$ & $12 y$ & $2 y 11 m$ & $148 / 169$ & $1 / 3$ \\
4 & $M$ & $15 y$ & $2 y 5 m$ & $187 / 203$ & $1 / 3$ \\
5 & $M$ & $20 y$ & $3 y$ & $166 / 212$ & $2 / 3$ \\
6 & $M$ & $14 y$ & $4 y 4 m$ & $196 / 201$ & $2 / 3$ \\
7 & $F$ & $21 y$ & $5 y 7 m$ & $157 / 162$ & $1 / 3$ \\
8 & $M$ & $19 y$ & $3 y 5 m$ & $138 / 183$ & $1 / 3$ \\
9 & $F$ & $18 y$ & $2 y 9 m$ & $170 / 184$ & $1 / 3$ \\
10 & $M$ & $18 y$ & $2 y 6 m$ & $163 / 177$ & $1 / 3$ \\
11 & $F$ & $11 y$ & $2 y 6 m$ & $180 / 215$ & $2 / 3$ \\
12 & $M$ & $15 y$ & $7 m$ & $147 / 197$ & $1 / 3$ \\
13 & $F$ & $11 y$ & $1 y$ & $186 / 172$ & $1 / 3$ \\
\hline
\end{tabular}

*Patient's age at postoperative interview; **CP: seizures control perception.

Table 2. Comparison between pre- and postoperative assessments.

\begin{tabular}{lccc}
\hline Analyzed aspects & Preoperative & Postoperative & p-value* $^{*}$ \\
\hline Health & 12.8 & 17.8 & 0.0024 \\
Physical & 28.8 & 31.2 & 0.0635 \\
Medication effects & 8.4 & 11.0 & 0.0010 \\
Emotional behavior & 33.8 & 32.7 & 0.4814 \\
Cognitive & 18.5 & 19.3 & 0.2803 \\
Social & 14.0 & 14.4 & 0.6855 \\
Schooling & 37.2 & 42.2 & 0.0791 \\
Environment & 12.2 & 14.5 & 0.0039 \\
Total & 162.4 & 185.4 & 0.0024 \\
\hline
\end{tabular}

*Wilcoxon's test

With respect to the overall outcome of QOL, the survey found that almost all patients showed significant improvement, which concurs with other results ${ }^{3,14,16-18,22-27}$. Despite the excellent control of seizures, only one of our patients had a decrease in the overall QOL score (subject 13), mainly due to social, school and behavioral factors. Our excellent results are superior to those found in other studies, because almost all of our patients benefitted from surgery. This is probably due to the fact that the selection for epilepsy surgery followed very strict criteria when the program was implemented. Another explanation is the fact that our study aimed exclusively at assessing patients undergoing surgery for TLE, unlike several other studies ${ }^{16-19,20,22,25-27}$, which analyzed the surgical results of all refractory epilepsy in childhood, thus including different epilepsies, often more severe than TLE. Another consideration is the long-term follow-up of our study. The average time between the pre- and postsurgery was 3.8 years.
All subjects indicated a high level of perception of seizure control (attributed to a maximum value when questioned about it). Other studies have also found a high degree of seizure control ${ }^{14,16,19,26}$ and positive correlations between the control and the degree of patient satisfaction $^{14,16,17,23-28}$. However, our findings were higher than those of the literature and, again, this is probably due to the strict inclusion criteria in our study and the fact that we have focused on surgery for TLE only, excluding other more serious etiologies.

The variables with significant influence on the improvement of QOL after surgery for TLE were: general health ${ }^{18,27,29}$, the negative effects of $\mathrm{AEDs}^{22,26}$ and parental behavior in relation to their children ${ }^{14,22,25}$. Mikati et al. ${ }^{18}$ found that the severity of symptoms, side effects of medication, general health and well-being improved after surgery, leading to consequent improvement of QOL. The general health and QOL also improved, according to a study by Markand et al. ${ }^{29}$. However, these authors also 
indicated an improvement in other aspects (emotional, cognitive, physical and social), in contrast to the present study. The improved relationship with parents is a result of their changing their behavior toward the child or adolescent. According to Souza et al. ${ }^{30}$, parents may have overprotective reactions, exaggerated permissiveness and excessive observation because of the epilepsy, which leads to many restrictions or difficulties in imposing disciplinary boundaries on their children. These behaviors interfere with the patient's QOL. Smith et al. ${ }^{25}$ reported that the elimination of seizures in patients after surgery improves family relationships, as there is improvement in communication and family cohesion, and conflict reduction. Also, according to these authors, mothers feel more able to promote and encourage the development of autonomy and independence in their children. The study by Elliott et al. ${ }^{22}$ surveyed the perceptions of the QOL of adolescents and their mothers. Although markedly different perceptions were noted between mothers and their children, for both, the main positive change ( $85 \%$ and $70 \%$, respectively) was in family relationships.

Of the 13 patients interviewed, only five of them are off medication, and the remaining eight are still on treatment (mono or polytherapy) with AEDs. However, the current use of drugs does not appear to have a significant impact on the QOL.

In summary, our data showed that, in relation to general health issues, there was improvement in all assessed parameters (physical, emotional, social, educational and leisure); with respect to side effects of AEDs, there was a significant improvement, with reduction of effects of AEDs; in the relationship with parents, there was improvement, mainly in the parents' behavior toward their children. Thus, we conclude that surgery for epilepsy, when well indicated, improves the QOL of children and adolescents with TLE.

\section{REFERENCES}

1. Guerreiro C, Guerreiro M, Cendes F, Lopes-Cendes I. Considerações gerais. IN: Guerreiro CAM, Guerreiro MM, Cendes F, Lopes- Cendes I (Eds). Epilepsia Campinas, São Paulo, 2000:1-10.

2. Gomes MM. Epidemiologia: distribuição, fatores de risco e considerações prognósticas. IN: Guerreiro CAM, Guerreiro MM, Cendes F, Cendes IL (Eds). Epilepsia Campinas, São Paulo, 2000:11-21.

3. Frayman L, Cukiert A. Qualidade de vida de pacientes submetidos à cirurgia de epilepsia. Arq Neuropsiquiatr 1999;57:30-33.

4. Devinsky O, Westbrook L, Cramer J, et al. Risk factors for poor health-related quality of life in adolescents with epilepsy. Epilepsia 1999;40:1715-1720.

5. MacLeod JS, Austin JK. Stigma in the lives of adolescents with epilepsy: a review of the literature. Epilep Behav 2003;4:112-117.

6. Filho HSM, Streiner DL, Gomes MM. Quality of life among Brazilian children with epilepsy: validation of a parent proxy instrument (QVCE-50). Seizure 2007;16:324-329
7. Camfield C, Breau L, Camfield P. Impact of pediatric epilepsy on the family: a new scale for clinical and research use. Epilepsia 2001;42:104-112.

8. Dunn DW. Neuropsychiatric aspects of epilepsy in children. Epilep Behav 2003:4:101-106.

9. Landgraf JM, Abetz L, Ware JE. Child health questionnaire $(\mathrm{CHO})$ : a user's manual, first ed., Boston, MA: The Health Institute, New England Medical Center, 1996.

10. Austin JK, MacLeod J, Dunn DW, et al. Measuring stigma in children with epilepsy and their parents: instrument development and testing. Epilep Behav 2004;5:472-482

11. Filho HSM, Gomes MM, Fontenelle LMC. Development and validation of a health related quality of life questionnaire for Brazilian children with epilepsy. Arq Neuropsiquiatr 2005;63:389-394.

12. Sabaz M, Lawson JA, Cairns DR, et al. Validation of the quality of life in childhood epilepsy questionnaire in American epilepsy patients. Epilep Behav 2003:4:680-691

13. Costa JC, Portela EJ. Tratamento cirúrgico das epilepsias na infância. J Epilepsy Clin Neurophysiol 2006;12(Suppl 1):S32-S43.

14. Guimarães CA, Souza EAP, Guerreiro MM, et al. Cirurgia para epilepsia na infância: avaliação neuropsicológica e de qualidade de vida. Arq Neuropsiquiatr 2003;61:786-792.

15. Guimarães CA. Avaliação neuropsicológica e de qualidade de vida em crianças submetidas à cirurgia para epilepsia. Tese. Campinas, 2000.

16. Empelen RV, Schinkel AJ, Rijen PCV, et al. Health-related quality of life and self-perceived competence of children assessed before and up to two years after epilepsy surgery. Epilepsia 2005;46:258-271.

17. Griffiths SY, Sherman EMS, Slick DJ, et al. Postsurgical health-related quality of life (HRQOL) in children following hemispherectomy for intractable epilepsy. Epilepsia 2007;48:564-570.

18. Mikati MA, Rahi AC, Shamseddine A, et al. Marked benefits in physical activity and well-being, but not in functioning domains, 2 years after successful epilepsy surgery in children. Epilep Behav 2008;12:145-149.

19. Lendt M, Helmstaedter C, Kuczaty S, et al. Behavioural disorders in children with epilepsy: early improvement after surgery. J Neurol Neurosurg Psychiatry 2000;69:739-744.

20. Hannan S, Cross JH, Scott RC, et al. The effects of epilepsy surgery on emotions, behavior, and psychosocial impairment in children and adolescents with drug-resistant epilepsy: a prospective study. Epilep Behav 2009;15: 318-324.

21. Lendt M, Helmstaedter C, Elger CE. Pre- and postoperative neuropsychological profiles in children and adolescents with temporal lobe epilepsy. Epilepsia 1999;40:1543-1550.

22. Elliott I, Lach L, Smith ML. Adolescent and maternal perspectives of quality of life and neuropsychological status following epilepsy surgery. Epilepsy \& Behavior 2000;1:406-417.

23. Aydemir N, Ozkara C, Canbeyli R, Tekcan A. Changes in quality of life and self-perspective related to surgery in patients with temporal lobe epilepsy. Epilep Behav 2004;5:735-742.

24. Bien CG, Bonhage AS, Soeder BM, et al. Assessment of the long-term effects of epilepsy surgery with three different reference groups. Epilepsia 2006; 47:1865-1869.

25. Smith ML, Elliott IM, Lach L. Cognitive, psychosocial and family function one year after pediatric epilepsy surgery. Epilepsia 2004;45:650-660.

26. Sabaz M, Lawson A, Cairns DR, et al. The impact of epilepsy surgery on quality of life in children. Neurology 2006;66:557-561.

27. Larysz D, Larysz P, Mandera M. Evaluation of quality of life and clinical status of children operated on for intractable epilepsy. Childs Nerv Syst 2007; 23:91-97.

28. Keene DL, Loy-English I, Ventureyra EC. Patient satisfaction with surgical treatment of refractory epilepsy done in childhood and early adolescence. Childs Nerv Syst 1998;14:30-32.

29. Markand ON, Salanova V, Whelihan E, Emsley CL. Health-related quality of life outcome in medically refractory epilepsy treated with anterior temporal lobectomy. Epilepsia 2000;41:749-759.

30. Souza EAPS, Nista CR, Scotoni AE, Guerreiro MM. Sentimentos e reações de pais de crianças epilépticas. Arq Neuropsiquiatr 1998;56:39-44. 